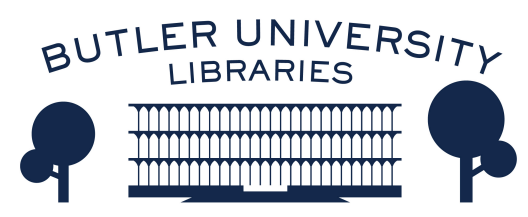

Journal of Hindu-Christian Studies

Volume 21

Article 24

January 2008

\title{
Book Review: "Song Divine: Christian Commentaries on the Bhagavad Gita"
}

Michael T. McLaughlin

Follow this and additional works at: https://digitalcommons.butler.edu/jhcs

Part of the Religion Commons

\section{Recommended Citation}

McLaughlin, Michael T. (2008) "Book Review: "Song Divine: Christian Commentaries on the Bhagavad Gita"," Journal of Hindu-Christian Studies: Vol. 21, Article 24.

Available at: https://doi.org/10.7825/2164-6279.1423

The Journal of Hindu-Christian Studies is a publication of the Society for Hindu-Christian Studies. The digital version is made available by Digital Commons @ Butler University. For questions about the Journal or the Society, please contact cbauman@butler.edu. For more information about Digital Commons @ Butler University, please contact digitalscholarship@butler.edu. 


\section{Song Divine: Christian Commentaries on the Bhagavad Gita. Ed. Catherine Cornille. Leuven--Paris--Dudley, Ma; Peters--B. Eeerdmans, 2006, 219p.}

THIS collection is a well edited and well focused series of experiments in the emerging discipline of Comparative Theology. It is the first of a series of commentaries on nonChristian sacred texts, with others soon to appear.

It will not be possible to summarize all of the rich content here. I have focused on a few of the many contributions for the sake of illustrating the kinds of discussions and comparisons which are going on.

Reid Locklin, in "The Cosmic Tree, Creation and Eschatology: Soundings from the Bhagavad Gita 15," focuses on one section and one image in the Gita which he nonetheless situates in the context of the larger work. The task is to probe the cosmic tree as a symbol of the cosmos and to relate the Christian image to that of the cross as axis mundi.

It is difficult to summarize this careful analysis in the space of a few words. In locating the meaning of this image he draws on Shankara, Ramanuja and Mircea Eliade. Locklin helps us to see how Shankara works on this image, elaborating it in a direction which will assist him in his goal of relating the tree to the inherent non-dualism of reality. He indicates that the tree is "subject to hundreds of doubts, for example, he clarifies the trees status as properly non -existent and finally applies to the tree the axe of detachment. The self and Brahman are one. Knowledge of this alone, not ritual and not good deeds, suffices.

Locklin contrasts this with Ramanuja's Visistadvaita or "qualified non-dualist" reading of the cosmic tree. In Ramanuja's view individual finite selves can be regarded as enduring "modes" or "modifications" of the divine self and corporal bodies as "modes" of these souls, the whole generated by Lord Vishnu for his pure enjoyment. Not surprising then, the cosmic tree will be rewritten in this image. Thus the tree does not describe God's entire creation, but only as bound by karma, attachment, and desire while God remains the supreme controller. God is different in kind from his creation. One takes refuge in the Lord, but unlike in Shankara, liberation can be attained only after death. Eliade's work, as we expect, surveys a variety of cross-cultural tree-related hierophanies. Locklin then moves forward to find a kind of "realized eschatology" in the Gita by which the power of the gunas is overcome. $\mathrm{He}$ sets this up using terminology from Ramanuja in which God's "accessibility" (saulabhya) is contrasted with God's "supremacy" (paratva) rather than as an immanent/transcendent polarity.

In a move of explicit comparison, Locklin tries to relate the Gita's verse, "The undeluded march ahead to that state which knows no change" to the Christian understanding of the cross and resurrected life, turning to Paul's already/not yet theme in Rom 8:22-25 in which "all creation groans" and yet "we have the first fruits of the spirit".

What exactly is going on when we pass from a "soulish" psychikos body to a pneumatikos one (1 Cor 15:44-46)? The reflective reader may at least realize the deep metaphoricity that one encounters either in saying that one goes beyond the gunas or that one leaves psychikos for pneumatikos. The final few pages are probably among the best yet the briefest of the essay. The author looks at resurrection with Hindu eyes and at pada with Christian eyes. As Christians we may wish to see our "soulish creation" as intertwined with the divine light and air as much as is the cosmic tree. Locklin is careful to note that that Ramanuja's cosmology, "a universe with infinite duration with cycles of creation and dissolution" does not completely overlap with the Christian one.

Steven Tsoukalas helps us to understand the different concepts of avatar in Shankara, Ramanuja, and Madhva. His concise descriptions of each position have produced an article which will be useful to those who want a clear orientation to this problem. It is an article which would be very useful to advanced 
students who need a starting point on this issue. There is an interesting section on the problematic historicity of the figure of Krishna and what it may mean for Hindu belief. Although the historicity of Jesus is less problematic, and despite the belief that he reveals who the Triune God is in and of himself, it could be added that the historicity of many of the episodes of the Gospels has certainly been a matter of fierce debate.

Jacques Scheuer reads the Gita as a guide for spiritual discernment, bringing it into conversation with the well known text in Catholic spirituality, the Spiritual Exercises of Saint Ignatius of Loyola, the founder of the Jesuit religious order. The Exercises were meant as a guide for the seeker who is asked to choose Christ as his king and battle for his kingdom in this world. In the Gita, of course, Arjuna is cast as this kind of person, one at the crossroads who must assume his godly responsibilities in this world. The Gita, like the Exercises, asks one to overcome inordinate attachments. Arjuna's choice to follow the dharma will have social and political consequences, not just religious and cosmic ones, much as the choice of the exercitant will. And yet the disciple is asked to look to the Lord as his model for action: "If I were not tirelessly to busy myself with works, ....these worlds would fall into ruin" $(3: 23-24)$. Scheuer finds that the spirit of bhakti is not foreign to the Exercises nor is the desire for a divine colloquy foreign to the Gita. The Christian idea that all is grace accords well with the Gita's emphasis that we are all instruments "twirled by the Lord's uncanny power" in a way that might astonish us if we could see it. (18:60).

This effort by Sheuer, in addition to the interesting article by Michael Barnes, "With God in the World: A Dialogue between the Bhagavad Gita and the Spiritual Exercises", which gives much more historical background on the Exercises, shows that the Gita, too, can be read as a text for spiritual discernment and decision. As Barnes notes, despite deep differences both texts are concerned with the right channeling of desire in order that God may be found in all aspects of life, great and small, in a mysticism of the everyday.

Rachel Fell McDermott in "Gifts to an Anglican from Krishna's Council" offers a reading of Krishna from an Anglican perspective, though she is also a scholar of Hinduism. Her article is helpful as a clarification of the differences between the story and message of Jesus and that of Krishna. More than other contributors in the volume, she plumbs the New Testament for parallels, convergences and divergences from the Gita and does so in a skillful manner. She focuses on three themes in her analysis: surrender to duty, the peace of equanimity as a sign of the God intoxicated soul, and the "accessibility" of God. For me her essay raises the question of whether gifts from Krishna's counsel can be received in an Anglican and also a Roman Catholic context in which issues of authority, orthodoxy, sexuality, and the political meaning of liberation have become so conflictual.

Joseph S. O'Leary's article raises the problem of political action and even religious fundamentalism as these might emerge from readings of the Gita and the fourth gospel. $\mathrm{He}$ notes that texts which offer a mystical solution to ethical and political (including church political) problems can be quite dangerous. This issue really does not find resolution in his article despite some unusual detours through writers such as T. S. Eliot. These are times in which most readers are uneasy with religious justifications for warfare, I think, precisely because we are so aware of how our perceptions can be manipulated.

The volume concludes with a brief article by Francis Clooney, a leading figure in the comparative theology movement, "Surrender to God Alone: the Meaning of the Bhagavad Gita 18:16 in Light of Srivaisnava and Christian Tradition." He provides a helpful philological study of the resonances of Sanskrit terms in this verse in context, including the commentary on it by Vedanta Desika $\left(14^{\text {th }}\right.$ c.) in the Sri Vaisnava stream of tradition going back to Ramanuja ( $11^{\text {th }}$ c.) Clooney is careful not to force similar Christian texts to mean exactly what the Gita means, and he usefully asks to what kind of practitioner the Gita text is addressed. The essay shows that much can be gained by a slow and careful explanation of a beloved text of the Gita as it percolates through centuries of commentators.

Michael T. McLaughlin

Saint Leo University 